\title{
PERFORMANCES OF SIMENTAL AND CROSSBREED ONGOLE IN FATTENING BEEF CATTLE USING CASSAVA WASTE
}

\author{
A. A. Candra, Y. Sukaryana and R. Noviadi
}

\author{
Department of Animal Husbandary of State Politechnic of Lampung \\ Soekarno-Hatta Street No. 10 District Rajabasa, Province Lampung, Indonesia
}

\begin{abstract}
The purpose of this article was to examine the performance Simental cattle and crossbreed ongol (CO) in Fattening Beef Cattle Semi Intensive Systems Based Cassava Waste. Research was to use of 10 heifer divided into two groups; simental and crossbreed ongol (CO) strain. Heifer were given feed treated with the main feed ingredient cassava waste of skin and combined with the concentrate. The research that was heifer simental better response in Fattening Beef Cattle Semi Intensive System for the increase of body weight $43.7 \mathrm{~kg}$ and average daily gain 0.73 crossbreed ongol (CO) $33.3 \mathrm{~kg}$ and 0.59 Average daily gain. In this study Simental cows have a better response in feedlot beef cattle kereman system using cassava peel waste as compared to cow's main food ingredients hybrid ongol.
\end{abstract}

Key words: Cattle performances, Peranakan ongol, Simental, Cassava Waste

\section{INRTRODUCTION}

Indonesia is tropical country that is very suitable for beef cattle production. Beef cattle production industry as an agribusiness activity has a very broad scope. Chain of events is not limited to activities in the upstream production but also to business activities in the downstream and all the business activities of its supporters . The majority of the people of beef cattle production in Indonesia carried out with the traditional system. That's why the production is not maximized and should be supplemented with imported cattle.

To meet the needs of beef cattle, Indonesia perform such import 500,000 heads of cows and 72 thousand tons of frozen meat (equivalent to 220,000 head) in 2011. While the contribution of beef to the level of national meat consumption reached 390 thousand tons (about 21\%). Meat livestock Australia in 2011 stated that until the end of 2011, Indonesia has imported 520987 head of cows. Decreases in the amount of approximately $33 \%$ compared to the previous year reaching 772868 tails. This decline occurred one of which caused an increase in local beef cattle population in 2014 to support self-sufficiency in meat.

Before the 1980s, beef cattle breeding business in Indonesia are traditional. Raising cattle by farmers generally in relatively small quantities and are backyard farming. Cattle functioned as savings. In some areas such as in the province of Nusa Tenggara Timur and Nusa Tenggara Barat where there is pasture ownership levels may be greater, yet still traditional system. The program developed by the government are generally limited to genetic quality improvement through artificial insemination program or the spread of local cows or move the location to the transmigration areas. In other words, livestock operations have been concentrated in the upstream segment and is still in a very small scale.

Lampung province, with an area of 3,528,835 ha \pm has the potential of natural resources that are very diverse, prospective, and reliable, ranging from agriculture, plantation, fishery, animal husbandry, mining, tourism, forestry. Lampung has a beef cattle fattening enterprise (feedlotters), the largest in Indonesia with total beef cattle population reached 428 thousand heads or equal to $60 \%$ of the total national population of beef cattle in feedlotter. While the department of Animal Husbandry and Animal Health Lampung Province released data that beef cattle population in Lampung 381.934 cattle managed by the people. The province is also known as a producer of maize, cassava, and fine bran concentrate as raw material that is needed by cattle. Potential cassava in the province of Lampung very large this should be utilized as much as possible so as to help improve the welfare of the people. Most of the cattle ranchers in Lampung is cultivated by people with small-scale farms and maintained extensive. This maintenance system forcing people should look for grass as a staple food for cattle.

*Corresponding e-mail address: adicandra@polinela.ac.id 


\section{A. A. Candra and others}

Therefore, it is necessary to study and test the use of cassava waste into cattle feed ingredients for people with better maintenance technology that bovine growth can be controlled better and the people no longer need to rely heavily on the extensive system for grass.

The purpose of writing this article is to examine the utilization of cassava waste Appearance Cattle Simental and Peranakan ongole in Fattening Beef Cattle Semi Intensive System based Cassava Waste

\section{MATERIALS AND METHODS}

The method used in this study was the use of cattle simental and crossbreed ongol(CO). Stage of this research was to analyze the nutritional needs of cattle by concocting various waste-based feed ingredients into potions complete feed. Then the cows adapted to change from green feed into complete feed. The meaning of concentrates and complete feed is cassava peel waste as the main feed. Materials used as the base material concentrate in this study were rice bran, dried cassava, maize, sucrose. While the main feed was cassava peel waste. All of the material was calculated by the software Microsof Excel so obtained mix composition containing nutrients needed by beef cattle. The feed composition of the most inexpensive yet sufficient nutritional value to the growth of beef cattle was concentrated $2 \mathrm{~kg}$ per day per cow, cassava peel $15 . \mathrm{kg}$ per day per cow, grass $2 \mathrm{~kg}$ per day per cow

Field testing phase of livestock by using a formula that has been obtained in the first phase. In this phase of the testing performed using 10 cows were divided into two groups based on the type of cattle. The first group was derived simental (beef red) while the second group was the crossbreed ongole (CO). Both groups were kept in a cage and the same ration. Tools used include shovels, hoes, scales and scales cattle feed. The variables measured were weight gain and average daily growth of cattle.

\section{RESULTS AND DISCUSSION}

\section{Raising beef cattle farming techniques}

Technology introduced in this study is an adaptation technology for cattle to change the habits of grass feed into complete feed gradually. Gradual adaptation done for rumination process that typically occurs with green feed material can remain running even though the feed was changed. This process goes in stages with the pattern as shown in Table 1. With this method on day 11 cows have been able to totally revamped with a complete feed. Adaptability of cows can be seen with the discovery of physiological disorders due to changes in the feed in the form of bloating and diarrhea or does not want to eat. Early stage before maintenance is the stage adaptation. This stage is the stage for the introduction of a change from grass to feed so. Stages adaptation was performed by pattern as shown in Table 1.

Table 1. The pattern of adaptation to changes in feed in beef cattle

\begin{tabular}{lll}
\hline Day & Feed Treatment/Concentrate (\%) & Grass/Forage (\%) \\
\hline 1 & 5 & 95 \\
2 & 25 & 75 \\
2 & 50 & 50 \\
2 & 75 & 25 \\
2 & 85 & 15 \\
2 & 100 & 0 \\
11 Day Adaptation Period Feed & & \\
\hline
\end{tabular}

Feeding is done ad libitum restricted by means of the feed is given in place of feed, feeding one day do as much as four times that morning, noon, afternoon, and evening. Before the feed given to the next day residual unconsumed feed should be cleaned first, to increase the palatability (level A) to the new feed. In addition to food waste cassava was also given additional feed forage, given the type of grass and turf grass is king. The addition of forage done only to fulfill the nutritional deficiencies of the ration given.

At the beginning of cow maintenance provision of drinking water only once a day is in the afternoon, this is done to avoid Tympany because cattle are not familiar with a given feed. After several months of maintenance, drinking water was given twice a day, afternoon and evening. 


\section{Weight gain}

Appearance cow leather waste treatment using cassava as the main feed presented in Table 2.

Table 2. Appearance beef with complete feed

\begin{tabular}{lllll}
\hline Type cow / Variable & $\begin{array}{l}\text { The initial weight } \\
(\mathrm{BB} \pm \mathrm{SD})(\mathrm{kgs})\end{array}$ & $\begin{array}{l}\text { Weights final } \\
(\mathrm{BB} \pm \mathrm{SD})(\mathrm{kgs})\end{array}$ & $\begin{array}{l}\text { Body weight gain } \\
(\mathrm{kgs})\end{array}$ & $\begin{array}{l}\text { Average Daily Gain } \\
(\mathrm{ADG})(\mathrm{kgs})\end{array}$ \\
\hline Simental & $194 \pm 5,5$ & $237,6 \pm 11,5$ & $43,7 \pm 16,5$ & $0,73 \pm 0,28$ \\
Cross breed Ongole & $191 \pm 1,4$ & $224,5 \pm 0,7$ & $33,3 \pm 2,1$ & $0,59 \pm 0,03$ \\
\hline
\end{tabular}

From the results in Table 2 shows that simental have a better response to the mixed feed in this study. This was evidenced by weight gain better in cattle simental $43.7 \mathrm{~kg}$, while in cattle $\mathrm{CO}$ only able to increase the body weight of $33.3 \mathrm{~kg}$ for 60 days of maintenance. This suggests that the response of the red cow was better at converting feed from cassava peel waste into meat than cattle crossbreed ongole.

Appearance treatment of beef cattle can also be seen from the result that the average daily gain of cattle simental has the ability increase body weight by $0.73 \mathrm{~kg}$ per day, whereas only able CO cattle rose $0.5 \mathrm{~kg}$ per day. If judging from the content of nutrients that the use of skin cassava as the main feed along concentrate sufficient to meet protein and crude fiber needed cows so cows can grow well. The value of the nutrient content of the material in this study are presented in Table 3.

Table 3. Nutrient content of feed ingredients used in the study

\begin{tabular}{llll}
\hline Nutrient & Onggok $(\%)$ & Cassava Skin $(\%)$ & Concentrate $(\%)$ \\
\hline Water Content & 97,74 & 87,26 & 26,25 \\
Ash & 76,50 & 50,00 & 7,20 \\
Protein & 4,76 & 4,76 & 16,46 \\
Fat & 0,26 & 1,09 & 6,48 \\
Crude fiber & 3,60 & 9,86 & 12,09 \\
Calcium & 11,36 & 0,20 & 1,02 \\
Phosphor & - & 0,02 & 0,42 \\
\hline
\end{tabular}

Beef cattle industry, especially cattle when people have increasingly promoted by the government, this is because the consumption of beef in Indonesia continues to increase. Although the increase is not offset by the addition of an adequate production. The rate of increase in beef cattle population is relatively slow, ie $4.23 \%$ in 2007 (Directorate General of Livestock, 2007). The condition causes cattle contribute to the national meat production lower (Mersyah, 2005; Santi, 2008) resulting in a widening gap between demand and supply (Setiyono et al., 2007). In 2006, the level of beef consumption is estimated to 399.660 tonnes, or the equivalent of 1.70 to 2 million head of beef cattle (Koran Tempo, 2008), while production of only 288.430 tonnes. The government projected levels of meat consumption in 2010 amounted to $2.72 \mathrm{~kg} /$ capita/year so that the needs of domestic meat reached 654,400 tons and the average rate of consumption growth of $1.49 \%$ / year (Badan Pusat Statistik, 2005). Beef cattle population in 2007 was 11.366 million head (Direktorat Jenderal Peternakan 2007). The population has not been able to keep pace with demand for beef continues to increase. To anticipate, the government to import beef and calves for fattening (Priyanti et al., 1998).

The import policy must be carried out although it will deplete foreign exchange, since local beef production has not been able to pursue the rate of increase in domestic demand, both quantity and quality (Priyanti et al., 1998; Yusdja et al., 2003). Data Direktorat Jenderal Peternakan 265.200 cattle (US\$107.731.000), beef 21.484.000 ton (US\$ 603.812.700), and beef liver 34.436.000 ton (US\$3.803.800). Of the total imports of the meat and cattle, $30 \%$ of which came from Australia, New Zealand, and the United States (Koran Tempo 2008).

In conclusion, Simental cows have a better response in feedlot beef cattle kereman system using cassava peel waste as compared to cow's main food ingredients hybrid ongol. 


\section{A. A. Chandra and others}

\section{REFERENCES}

1. BPS (2007). Lampung Dalam Angka.http://www.indonesia. go. id/id/index.php? option=com_content\&task = view\&id $=3533 \&$ Itemid $=1957$. Diakses tanggal 5 Maret 2010.2007.

2. Direktorat Jenderal Peternakan (2006). Statistik Peternakan. Direktorat Jenderal Peternakan, Jakarta.

3. Direktorat Jenderal Peternakan (2007). Statistik Peternakan. Direktorat Jenderal Peternakan, Jakarta.

4. Koran Tempo (2008). Indonesia belum siap impor sapi Brazil. Edisi Senin, 13 Oktober 2008, Jakarta.

5. Mersyah R (2005). Desain sistem budi daya sapi potong berkelanjutan untuk mendukung pelaksanaan otonomi daerah di Kabupaten Bengkulu Selatan. Disertasi, Sekolah Pascasarjana, Institut Pertanian Bogor.

6. Priyanti A, TD Soedjana, R Matondang and dan P Sitepu (1998). Estimasi sistem permintaan dan penawaran daging sapi di Provinsi Lampung. Jurnal Ilmu Ternak dan Veteriner 3: 71-77.

7. Santi WP (2008). Respons Penggemukan Sapi PO dan Persilangannya sebagai Hasil IB terhadap Pemberian Jerami Padi Fermentasi dan Konsentrat di Kabupaten Blora. Skripsi. Fakultas Peternakan Institut Pertanian Bogor.

8. Setiyono PBWHE, Suryahadi T and Torahmat dan R Syarief (2007). Strategi suplementasi protein ransum sapi potong berbasis jerami dan dedak padi. Jurnal Ilmu Pengetahuan dan Teknologi Peternakan 30: $207-217$.

9. Yusdja Y, Ilham N and dan WK Sejati (2003). Profil dan permasalahan peternakan. Forum Penelitian AgroEkonomi 21: 45-56. 